ACTA AGROBOTANICA

Vol. 59 z. 22006

s. 151162

\title{
Control of Fusarium head blight of winter wheat by artificial and natural infection using new fungicides
}

\author{
OLGA TREIKALE, IRINA AFANASJEVA, \\ JELENA PUGACHEVA \\ Latvian Plant Protection Research Centre, Lielvardes 36/38, LV 1006, \\ Riga, Latvia; e mail: olga.treikale@laapc.lv
}

(Received: 15.09.2006)

\section{$\mathrm{S}$ u m m a r y}

In Latvia, climatic factors are influential in spreading of Fusarium head blight of cereals caused by Fusarium species. The most significant factor affecting the incidence of the disease in winter wheat is hightened temperature at the time of wheat anthesis. Field trials for the control of the disease in winter wheat were done in 2003-2004 using new fungicides applied at various rates by natural infection and artificial inoculation. Three species of causative agents: Fusarium avenaceum var. herbarum, F. gibbosum, F. culmorum were collected from infected seeds of wheat and used for inoculation of experimental plots at the concentration $10^{6}$ conidia $\mathrm{ml}^{-1}(1: 1: 1)$ at the stage of full anthesis. Effective control of the disease was obtained through application of new fungicides with different active ingredient: Prosaro $250 \mathrm{EC}$ (tebuconazole $125 \mathrm{G}$, prothioconazole $125 \mathrm{G} \mathrm{L}^{-1}$ ), Input 460 EC (spiroxamine $300 \mathrm{G}$, prothioconazole $160 \mathrm{G} \mathrm{L}^{-1}$ ). In conditions of artificial infection by severe attack of Fusarium spp. the application of fungicides containing tebuconazole at T3 gave significant influence on yield of winter wheat through plumpness of grains increase. High efficacy of fungicides against leaf infection with Erysiphe graminis and Drechslera tritici-repentis was also in the trial achieved.

Application of fungicide containing cyproconazole and trifloxystrobin at $\mathrm{T} 1$ in the trial 2004 gave good control of Septoria tritici, E. graminis and D. triticirepentis.

Key words: winter wheat, Fusarium head blight, leaf diseases, fungicides, efficacy

\section{INTRODUCTION}

Fusarium head blight of wheat in last years is a very important worldwide disease in intensive growing of cereal. Ear fusariose has caused significant yield losses of winter wheat. During the 1990s, wheat producers in regions affected by 
Fusarium head blight have suffered cumulative losses of $\$ 1.3$ billion, according to analysis by J o h n s o n et al. (2003). In Russian total yield losses of winter wheat from Fusarium head blight reached to $44-88 \%$ (Ts u mak o v and $\mathrm{Z}$ a ha rova, 1990). Contamination of mycotoxins, what are produced by consumption Fusarium species in cereal grains, is a hazardous factor for using of these products in human foods and animal feeds. Species predominantly found associated with Fusarium head blight in Europe are F. graminearum, F. culmorum, F. avenaceum, F. sporotrichiella (Bottalico, 1998). F. culmorum predominates in grain crop in the Netherlands, Germany and northern Europe (M i elk e, 1988, P a rry et al. 1995). These species are the most widespread as seed-borne pathogens identified in winter wheat in Latvia, too ( $\mathrm{Tr}$ e ikale and Pugacheva, 2002).

Climate appears to be a major limiting factor in the distribution of many species of Fusarium (B a ckhou se et al. 2002). More observers have noted relationships between high humidity during the flowering and fusarium head blight occurence (B u s h nell et al. 2003). In Latvia, climatic factors are influential in spreading of fusarial head blight of cereal caused by Fusarium species. Control of ear fusarioses in wheat is a complex problem. The most significant factor affecting the incidence of fusarial head blight in winter wheat in Latvia is hightened temperature at the time of anthesis of wheat. Usually, average temperature during the flowering of winter wheat in the third ten-days period of June in Latvia is not higher than $17^{\circ} \mathrm{C}$ but air humidity is high in a result of frequent rain. Using of fungicides in this period is limited by wet weather conditions, fusarium control is depending on efficacy of fungicides and riskiness of their residues uptake into the yield. Only a few very effective active ingredients are available for control of fusarial head blight, from them tebuconazole showed very good efficacy against Fusarium spp. development on ears of wheat (M i e l$\mathrm{ke}$ et al. 1996; Mesterhazy et al. 2001). The tebuconazole treatment increased plot yields by $21 \%$ and significantly decreased contamination of mycotoxins in grains of wheat (M a u le r- M a c h n i k et al. 1994). T var u z e k (2001) obtained good control of ear fusariosis after using of tebuconazole and significant reduce of mycotoxins concentration in harvested grains. In Latvia control of Fusarium head blight with fungicides which contain tebuconazole in intensive growing of wheat are apply in the last few years.

In this study effectiveness of new fungicides used at flowering of winter wheat in the control of Fusarium head blight and leaf diseases were evaluated.

\section{MATERIAL AND METHODS}

Field trials in 2003-2004 were carried out in sowing of winter wheat 'Kobra' in accordance with EPPO guidelines. Trials carried out in four replicates using randomized block design, with plot size of $30 \mathrm{~m}^{2}$. In the field trial of 2003 Prosaro $250 \mathrm{EC}$ (tebuconazole $125 \mathrm{G}$, prothioconazole $125 \mathrm{G} \mathrm{L}^{-1}$ ) and Input $460 \mathrm{EC}$ (spiroxamine $300 \mathrm{G}$, prothioconazole $160 \mathrm{G} \mathrm{L}^{-1}$ ) have been tested by artificial infection with F. culmorum, F. avenaceum var. herbarum, F. gibbosum, a plot size $12 \mathrm{~m}^{2}$. Plots were inoculated at flowering stage with causative agents isolated from infected ears of 
winter wheat and propagated on PDA. Plots were inoculated by spray with knapsack sprayer in favourable weather conditions for infection: high air temperature $\left(+20^{\circ} \mathrm{C}\right)$ and air humidity after rain (99\%). Concentration of conidias by inoculation was $10^{6} \mathrm{ml}^{-1}$, volume ratio: 1:1:1. Application of fungicides has been 6 days later. Weather conditions during the flowering of winter wheat and in beginning of kernel formation were favourable for infestation of Fusarium head blight.

The trial in 2004 was carried out in conditions of natural infection. Orius 250 EW (tebuconazole $250 \mathrm{G} \mathrm{L}^{-1}$ ) in dose $1.0 \mathrm{~L} \mathrm{ha}^{-1}$ and Prosaro $250 \mathrm{EC}$ in doses 1.0 and $0.75 \mathrm{~L} \mathrm{ha}^{-1}$ have been tested by application at T3 compared with Folicur $250 \mathrm{EW}$ (tebuconazole $250 \mathrm{G} \mathrm{L}^{-1}$ ), Falcon $460 \mathrm{EC}$ (tebuconazole $167 \mathrm{G}$, triadimenol $43 \mathrm{G}$, spiroxamine $250 \mathrm{G} \mathrm{L}^{-1}$ ) and Juventus 60 (metconazole $60 \mathrm{G} \mathrm{L}^{-1}$ ) used at the same time. In the trial application of fungicide Sfera $267.5 \mathrm{EC}$ containing cyproconazole $\left(80 \mathrm{G} \mathrm{L}^{-}\right.$ $\left.{ }^{1}\right)$ and trifloxystrobin $\left(187.5 \mathrm{G} \mathrm{L}^{-1}\right)$ at $\mathrm{T} 1$ was carried out. In 2004 low air temperature at flowering of wheat was not favourable for infection of ears.

Fusarium head blight was assessed on 100 randomly selected ears in each plot. Observations on leaf diseases were assessed as percentage of all green leaves by the each individual disease. Diseases incidence and severity were assessed with 7 days interval at 25 randomly selected plants in each plot.

Yield was harvested with grain harvester of small cut. The grain yield was corrected to $100 \%$ purity ant to standard grain moisture $15 \%$ content. TGW was measured. Experimental data were subjected to analysis of variance, treatment means were separated at the $95 \%$ probability level using F-test with program of variance analysis.

\section{RESULTS}

\section{Control of leaf diseases}

In conditions of 2003 in winter wheat moderate attack of Erysiphe graminis was observed. Before fungicides application the severity of the disease was $2.32 \%$. Development of powdery mildew in untreated plots was reached to $12.2 \%$ at the GS 72 (Fig. 1).

Prosaro in doses $0.75 \mathrm{~L}$ and $1.0 \mathrm{~L} \mathrm{ha}^{-1}$ and Input in dose $1.0 \mathrm{~L} \mathrm{ha}^{-1}$ were effective to control powdery mildew. Both fungicides significantly retarded the development of $E$. graminis on leaves of winter wheat. In milky ripeness stage severity of the disease was $0.4-0.6 \%$. Application of Prosaro and Input gave good control of E. graminis in winter wheat during the three weeks. The effectiveness of new fungicides was on the level of azole products used in the trial at the same time: Folicur, Falcon and Juventus (Table 1).

In conditions of 2003 epiphytotic development of tan spot (Drechslera tritici-repentis) was marked in winter wheat. Before application of fungicides, at the GS 65 , in the trial $100 \%$ infestation of D. tritici-repentis by severity to $10.5 \%$ was marked. Tan spot in control-untreated during the following two weeks was developed to $25.1 \%$. The severity of tan spot on the top leaves of winter wheat at GS 75 was $80.6 \%$ (Fig. 2). 


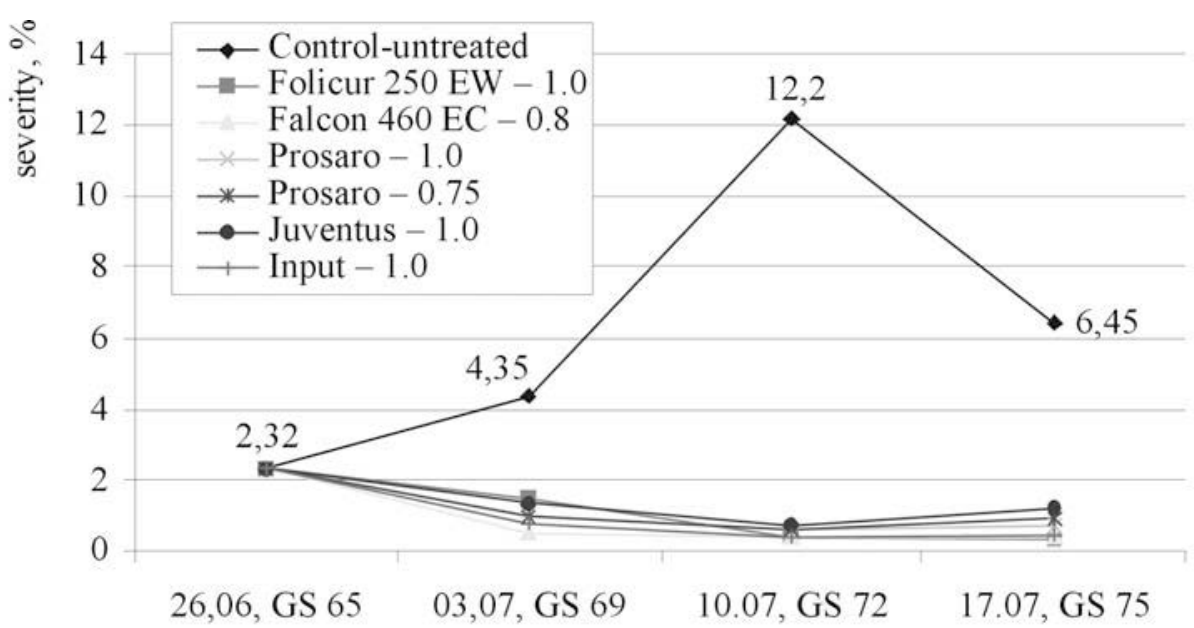

Fig. 1. Development of Erysiphe graminis in the winter wheat (trial 2003).

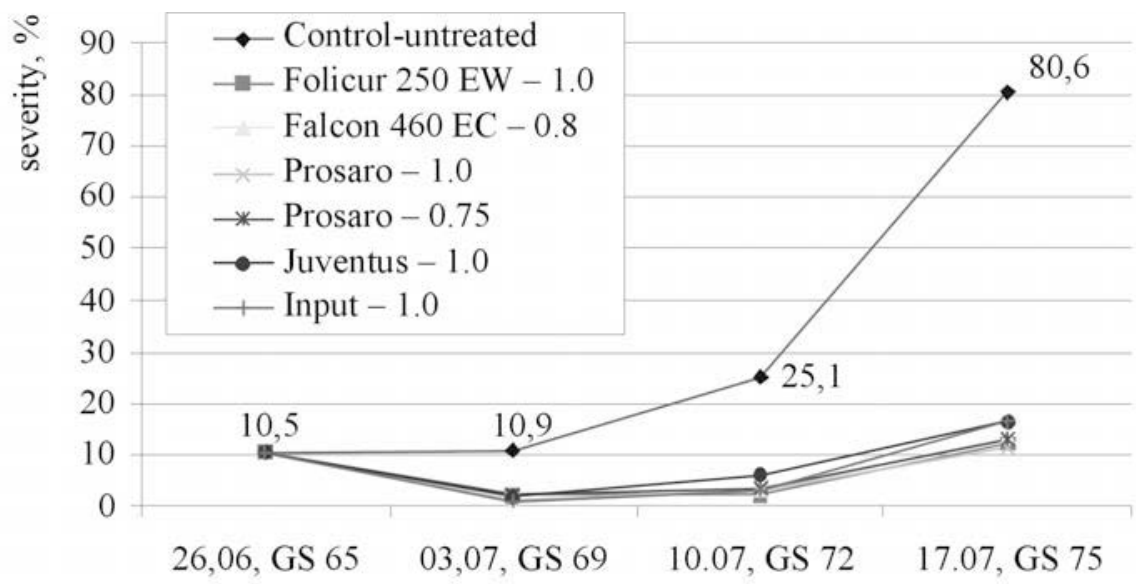

Fig. 2. Development of Drechslera tritici-repentis in the winter wheat (trial 2003).

Application of fungicides significantly decreased the development of tan spot. One week after application efficacy of Prosaro in doses 0.75 and $1.0 \mathrm{~L} \mathrm{ha}^{-1}$ in the control of tan spot was about $80 \%$. Prosaro was effective in the control of tan spot during the two weeks after application: about $87 \%$ (Table 2). 
Table 1

Efficacy of the fungicides in the control of Erysiphe graminis on winter wheat (2003).

\begin{tabular}{|c|c|c|c|c|c|}
\hline \multicolumn{2}{|c|}{$\begin{array}{l}\text { Previous: winter wheat } \\
\text { Sowing: } 29.09 .2002 \\
\text { Harvesting: } 07.08 .2003\end{array}$} & \multicolumn{2}{|c|}{$\begin{array}{l}\text { Soil: soddy-calcareous, } \mathrm{pH} 7.0 \\
\text { Organic matter content: } 2.1 \% \\
\text { Fertilizing: } \mathrm{N}_{12} \mathrm{P}_{52} \mathrm{~K}_{60}+\mathrm{N}_{90}\end{array}$} & \multicolumn{2}{|c|}{$\begin{array}{l}\text { Application: } 26.06 .2003, \text { GS } 65 \\
\text { Equipment: knapsack sprayer }\end{array}$} \\
\hline \multirow[t]{2}{*}{ Treatments } & \multirow{2}{*}{$\begin{array}{l}\text { Dose, } \\
\text { L }^{-1}{ }^{-1}\end{array}$} & \multicolumn{2}{|c|}{10.07 , GS 72} & \multicolumn{2}{|c|}{ 17.07, GS 75} \\
\hline & & Severity, \% & Effect, $\%$ & Severity, $\%$ & Effect, $\%$ \\
\hline Control & untreated & 12.20 & - & 6.45 & - \\
\hline Folicur 250 & 1.0 & 0.39 & 96.7 & 0.33 & 94.9 \\
\hline Falcon 460 & 0.8 & 0.39 & 96.7 & 0.38 & 94.1 \\
\hline Prosaro & 1.0 & 0.60 & 95.1 & 0.70 & 89.1 \\
\hline Prosaro & 0.75 & 0.60 & 95.1 & 0.88 & 86.4 \\
\hline Juventus & 1.0 & 0.70 & 94.3 & 1.20 & 81.4 \\
\hline Input & 1.0 & 0.40 & 96.7 & 0.45 & 93.0 \\
\hline $\mathrm{LSD}_{95}$ & - & 8.37 & - & 2.85 & - \\
\hline
\end{tabular}

Table 2

Efficacy of the fungicides in the control of Drechslera tritici repentis in winter wheat (2003).

\begin{tabular}{|c|c|c|c|c|c|}
\hline \multicolumn{2}{|c|}{$\begin{array}{l}\text { Previous: winter wheat } \\
\text { Sowing: } 29.09 .2002 \\
\text { Harvesting: } 07.08 .2003\end{array}$} & \multicolumn{2}{|c|}{$\begin{array}{l}\text { Soil: soddy-calcareous, } \mathrm{pH} 7.0 \\
\text { Organic matter content: } 2.1 \% \\
\text { Fertilizing: } \mathrm{N}_{12} \mathrm{P}_{52} \mathrm{~K}_{60}+\mathrm{N}_{90}\end{array}$} & \multicolumn{2}{|c|}{$\begin{array}{l}\text { Application: 26.06.2003, } \\
\text { GS } 65\end{array}$} \\
\hline \multirow[t]{2}{*}{ Treatments } & \multirow{2}{*}{$\begin{array}{l}\text { Dose, } \\
\text { L ha }^{-1}\end{array}$} & \multicolumn{2}{|c|}{10.07, GS 72} & \multicolumn{2}{|c|}{17.07 , GS 75} \\
\hline & & Severity, $\%$ & Effect, $\%$ & Severity, $\%$ & Effect, $\%$ \\
\hline Control & untreated & 25.12 & - & 80.60 & - \\
\hline Folicur 250 & 1.0 & 2.05 & 91.8 & 12.30 & 84.7 \\
\hline Falcon 460 & 0.8 & 2.97 & 88.2 & 13.40 & 83.4 \\
\hline Prosaro & 1.0 & 3.17 & 87.4 & 11.09 & 86.2 \\
\hline Prosaro & 0.75 & 3.45 & 86.3 & 13.10 & 83.7 \\
\hline Juventus & 1.0 & 6.15 & 75.5 & 16.50 & 79.5 \\
\hline Input & 1.0 & 3.07 & 87.8 & 16.50 & 79.5 \\
\hline $\mathrm{LSD}_{95}$ & - & 3.33 & - & 10.25 & - \\
\hline
\end{tabular}

The fungicide Input in dose $1.0 \mathrm{~L} \mathrm{ha}^{-1}$ gave the same effect in the control of tan spot as Prosaro. One week after application Input gave very good effect $(91.5 \%)$ in the control of tan spot (Table 2). 
During the trial 2004 was observed slight level of attack with powdery mildew, severe infection by Septoria tritici and severe attack of tan spot (Fig. 3). Application of Sfera at the beginning of infestation of leaf diseases at T1 (GS 33) in the trial (including control) in dose $0.8 \mathrm{~L} \mathrm{ha}^{-1}$ was effective to delay of development of diseases during one month after spray. At T3 (GS 65) before application of fungicides to control of Fusarium head blight in the trial was observed slight infection of the leaf diseases (Fig. 3).

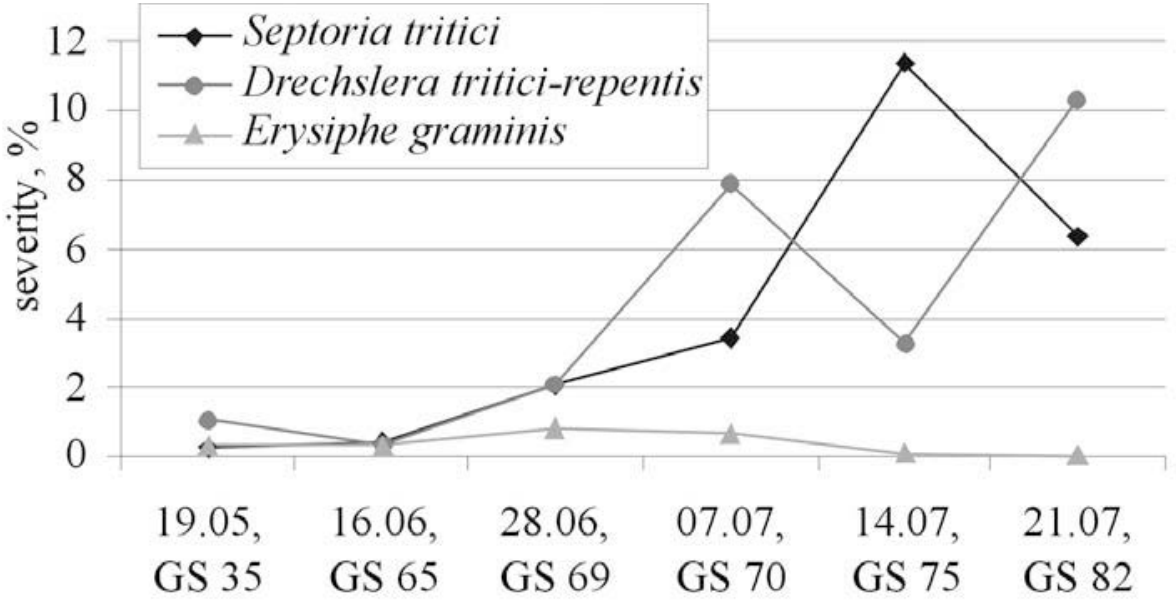

Fig. 3. Dynamics of leaf diseases development in winter wheat in the trial 2004.

Table 3

Effectiveness of fungicides in the control of Septoria tritici on winter wheat.

\begin{tabular}{|c|c|c|c|c|c|}
\hline \multicolumn{2}{|c|}{$\begin{array}{l}\text { Previous: winter wheat } \\
\text { Sowing: } 10.09 .2003 \\
\text { Harvesting: } 18.08 .2004\end{array}$} & \multicolumn{3}{|c|}{$\begin{array}{l}\text { Soil: soddy-calcareous, pH 7.0; Org. content: } 2.0 \% \\
\text { Fertilizing: } \mathrm{N}_{8} \mathrm{P}_{40} \mathrm{~K}_{40}+\mathrm{N}_{70}+\mathrm{N}_{70}+\mathrm{N}_{35} \\
\text { Sfera } 267.5 \mathrm{EC} 0.8 \mathrm{~L} \mathrm{ha}^{-1}\end{array}$} & $\begin{array}{l}\text { Application: } \\
16.06 .2004 \text {, GS } 65\end{array}$ \\
\hline \multirow[t]{2}{*}{ Treatments } & \multirow{2}{*}{$\begin{array}{l}\text { Dose, } \\
\text { Lha }{ }^{-1}\end{array}$} & \multicolumn{2}{|c|}{07.07, GS 70} & \multicolumn{2}{|c|}{14.07, GS 75} \\
\hline & & Severity, $\%$ & Effect, \% & Severity, ${ }^{\circ}$ & Effect, $\%$ \\
\hline Control & untreated & 3.45 & - & 11.35 & - \\
\hline Folicur 250 & 1.0 & 1.10 & 68.1 & 2.08 & 81.7 \\
\hline Prosaro & 1.0 & 0.50 & 85.5 & 1.55 & 86.3 \\
\hline Prosaro & 0.75 & 1.23 & 64.5 & 2.12 & 81.3 \\
\hline Falcon 460 & 0.8 & 0.78 & 77.5 & 2.28 & 79.9 \\
\hline Juventus 60 & 1.0 & 1.25 & 63.8 & 2.42 & 78.7 \\
\hline Orius 250 & 1.0 & 0.95 & 72.5 & 1.88 & 83.4 \\
\hline $\mathrm{LSD}_{95}$ & - & 0.68 & - & 2.62 & - \\
\hline
\end{tabular}


The efficacy of Prosaro in dose $1.0 \mathrm{~L} \mathrm{ha}^{-1}$ in the control of S. tritici 10 days after application was $80 \%$ and one month after application $86.3 \%$ (Table 3). Application of Orius in dose $1.0 \mathrm{~L} \mathrm{ha}^{-1}$ gave the same effect as Folicur.

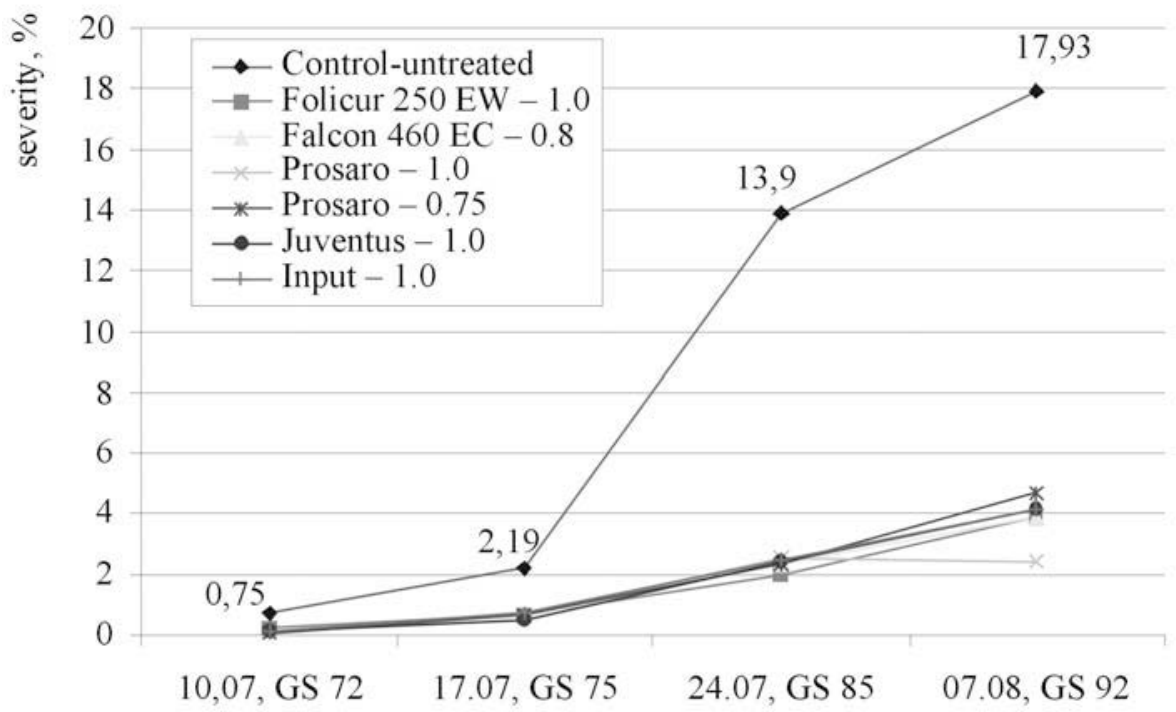

Fig. 4. Development of Fusarium head blight on winter wheat by artificial infection (trial 2003).

Table 4

Effectiveness of fungicides in the control of Fusarium head blight in winter wheat (2003).

\begin{tabular}{|c|c|c|c|c|c|}
\hline \multirow[t]{2}{*}{ Treatments } & \multirow{2}{*}{$\begin{array}{l}\text { Dose, } \\
\text { L ha }{ }^{-1}\end{array}$} & \multicolumn{2}{|c|}{10.07, GS 72} & \multicolumn{2}{|c|}{07.08 , GS 92} \\
\hline & & Severity, \% & Effect, \% & Severity, \% & Effect, \% \\
\hline Control & untreated & 2.19 & - & 17.93 & - \\
\hline Folicur 250 & 1.0 & 0.63 & 71.2 & 3.85 & 78.5 \\
\hline Falcon 460 & 0.8 & 0.56 & 74.4 & 3.90 & 78.2 \\
\hline Prosaro & 1.0 & 0.65 & 70.3 & 2.45 & 86.3 \\
\hline Prosaro & 0.75 & 0.65 & 70.3 & 4.67 & 74.0 \\
\hline Juventus & 1.0 & 0.50 & 77.2 & 4.15 & 76.9 \\
\hline Input & 1.0 & 0.74 & 66.7 & 4.17 & 76.7 \\
\hline $\mathrm{LSD}_{95}$ & - & 0.50 & - & 3.45 & - \\
\hline
\end{tabular}


In the control of leaf blotch by new fungicides and standard products: Falcon, Folicur, and Juventus no significant differences were found. In conditions of 2004 all fungicides during the month after application were effective in the control of tan spot and powdery mildew. Lower dosage of Prosaro showed slightly lower effect against leaf diseases.

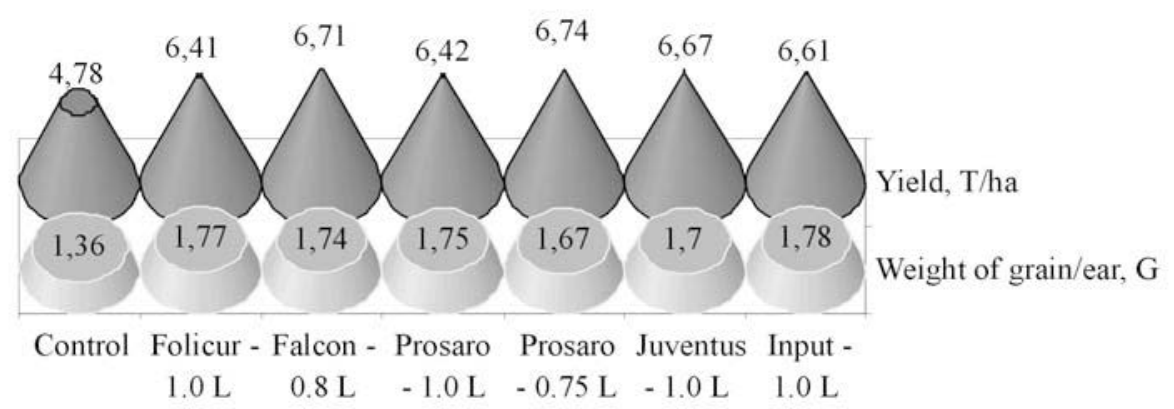

Fig. 5. The influence of application of the fungicides on yield of winter wheat (trial 2003).

\section{Control of Fusarium head blight}

In the trial of 2003 by artificial inoculation of winter wheat with Fusarium spp. at high air temperature and air humidity during the flowering period and in period of kernel formation (favours disease development) the disease spreading increased from $7.5 \%$ to $88.0 \%$ by severity from $0.75 \%$ to $13.9 \%$ in plots where fungicides were not used (Fig. 4). At the same time natural infection was developed from $0.5 \%$ to $8.5 \%$ (near field).

By high level of development of the disease the application of Prosaro gave good control of Fusarium spp. on ears of winter wheat. Efficacy of the fungicide in dose $1.0 \mathrm{~L} \cdot \mathrm{ha}^{-1}$ in the control of Fusarium head blight was $86.3 \%$. In lower dose Prosaro was less effective (74\%) (Table 4).

The efficacy of Input in the control of Fusarium head blight was 76.7\%. Efficacy of Prosaro in control of the disease about $80 \%$ was on the same level as Falcon in dose $0.8 \mathrm{~L} \mathrm{ha}^{-1}$, Folicur in dose $1.0 \mathrm{~L} \cdot \mathrm{ha}^{-1}$ and Juventus in dose $1.0 \mathrm{~L} \cdot \mathrm{ha}^{-1}$ used at the same time.

In conditions of 2003 leaf diseases and Fusarium head blight have significant influence on yield formation of winter wheat. Grain yield in control-untreated was $4.78 \mathrm{~T} \mathrm{ha}^{-1}$ (Fig. 5). By counting of number of grain and their weight per ear were found the significant differences between control-untreated and treatments with fungicides application. By application of Folicur and Input in dose $1.0 \mathrm{~L} \cdot \mathrm{ha}^{-1}$ was formed the most laden kernel: weight of grain per ear was on $31.0 \%$ higher than in untreated (Table 5). 
Table 5

Effectiveness of fungicides in the control of Fusarium spp. on ear of winter wheat (2003).

\begin{tabular}{|l|c|c|c|c|c|}
\hline \multirow{2}{*}{ Treatments } & Dose, & \multicolumn{2}{c|}{ Number of grains per ear } & \multicolumn{2}{c}{ Weight of grain per ear } \\
\cline { 3 - 6 } & $\mathrm{L} h a^{-1}$ & Number & $\%$ to control & $\mathrm{G}$ & $\%$ to control \\
\hline Control & untreated & 34.97 & 100.0 & 1.360 & 100.0 \\
\hline Folicur 250 & 1.0 & 40.23 & 115.0 & 1.767 & 129.9 \\
\hline Falcon 460 & 0.8 & 39.71 & 113.6 & 1.742 & 128.1 \\
\hline Prosaro & 1.0 & 39.21 & 112.1 & 1.752 & 128.8 \\
\hline Prosaro & 0.75 & 38.77 & 110.9 & 1.667 & 122.6 \\
\hline Juventus & 1.0 & 38.55 & 110.2 & 1.695 & 124.6 \\
\hline Input & 1.0 & 40.21 & 115.0 & 1.782 & 131.0 \\
\hline \multicolumn{1}{c|}{ LSD $_{95}$} & - & 2.70 & - & 0.109 & - \\
\hline
\end{tabular}

Table 6

Effectiveness of fungicides in the control of Fusarium head blight of winter wheat (2004).

\begin{tabular}{|c|c|c|c|c|c|}
\hline \multirow[t]{2}{*}{ Treatments } & \multirow{2}{*}{$\begin{array}{l}\text { Dose, } \\
\text { L.ha }^{-1}\end{array}$} & \multicolumn{2}{|c|}{ Fusarium head blight } & \multicolumn{2}{|c|}{ Yield } \\
\hline & & $\begin{array}{c}\text { Severity, } \\
\%\end{array}$ & $\begin{array}{l}\text { Biological } \\
\text { effect, \% }\end{array}$ & $\mathrm{T} \mathrm{ha}^{-1}$ & $\begin{array}{l}\text { Increase to } \\
\text { control, \% }\end{array}$ \\
\hline Control & untreated & 4.51 & & 8.71 & 100.0 \\
\hline Folicur 250 & 1.0 & 1.13 & 75.1 & 9.70 & 111.4 \\
\hline Prosaro & 1.0 & 0.66 & 85.5 & 9.42 & 108.2 \\
\hline Prosaro & 0.75 & 1.27 & 72.0 & 9.60 & 110.2 \\
\hline Falcon 460 & 0.8 & 1.75 & 61.3 & 9.39 & 107.8 \\
\hline Juventus 60 & 1.0 & 1.41 & 68.7 & 9.46 & 108.6 \\
\hline Orius 250 & 1.0 & 0.93 & 79.4 & 9.52 & 109.3 \\
\hline $\mathrm{LSD}_{95}$ & & 0.60 & & 0.45 & \\
\hline
\end{tabular}


The application of the fungicides in conditions of 2003 gave significant influence on yield of winter wheat in comparison with untreated. The increase of yield in average was higher than $30 \%$. TGW in all treatments was significantly increased compared with untreated.

Fusarium head blight in conditions of 2004 was observed on $78.8 \%$ ears, severity level was not high: $4.5 \%$ in untreated. All fungicides used at the flowering of winter wheat gave good control of the disease. Prosaro in dose $1.0 \mathrm{~L} \cdot \mathrm{ha}^{-1}$ gave better control of the disease: efficacy $85.5 \%$ (Table 6).

By application of Prosaro in dose $0.75 \mathrm{~L} \cdot \mathrm{ha}^{-1}$ the effectiveness against infestation of Fusarium ssp. on ears of winter wheat was lower, but in the treatment the disease severity was significantly delayed. The effectiveness of Orius against Fusarium spp. infection on ears of winter wheat was slightly higher than Folicur.

In conditions of 2004 the total grain yield of winter wheat in the trial was very high: $8.71 \mathrm{~T} \mathrm{ha}^{-1}$ in untreated. The grain yield was significantly increased in all treatments in comparison with untreated (Table 6). In all treatments with application of the fungicides TGW was significantly higher compared with untreated.

\section{DISCUSSION}

The investigations on effectiveness of fungicides in the control of Fusarium head blight in Latvia showed possibility and necessity of application of products which contain tebuconazole. Application of fungicides at T3 of winter wheat gave good control of the disease spread and development on ears. Most effective control in both trials showed Prosaro.

Assessment of number of grain/ear and their weight in condition of artificial inoculation in the trial 2003 showed on significant influence of Fusarium spp. infection of ear on forming of yield of winter wheat. Most important is the distribution of infection into the grain, which led to a significant decrease of germination of seeds and to development of root rot of seedlings of wheat after sowing. In our investigations (Treikale and Guzeva, 1996) from key pathogens identified as causative agents of root rot in winter wheat $77 \%$ belong to Fusarium ssp., in spring wheat from 63 to $87 \%$ of all causative agents were Fusarium ssp.: F. culmorum, F. gibbosum, F. sambucinum, F. avenaceum v. herbarum, F. oxysporum.

Effective control of Fusarium head blight can obtained through application of fungicides with different active substance in two times: at T1 and at T3. In the trial 2004 in intensive growing of winter wheat high efficacy of application of fungicides containing cyproconazole and trifloxystrobin at T1 to control of leaf diseases (Septoria tritici, Erysiphe graminis, Drechslera tritici-repentis) was achieved, the application of fungicides containing tebuconazole at $\mathrm{T} 3$ gave significant influence on yield of winter wheat and TGW. Intensification of farming where winter wheat will be growth by intensive technologies in accordance with agrotechnical requirements and by integrated crop protection will make it possible significantly decrease ear fusarioses and greatly redused the mycotoxin content in the grains. 


\section{REFERENCES}

Backhouse D., Burgess L. W., Summerell B. A., 2002. Biogeography of Fusarium. Pages 122137 in: Fusarium Paul E. Nelson Memorial Symposium. The American Phy topathological Society, 392.

B ottalico A., 1998. Fusarium diseases of cereals: species complex and related mycotoxin profiles, in Europe. Plant Pathol. 80: 85103.

Bushnell W. R., Hazen B. E., Pritsch C., 2003. Histology and Physiology of Fusarium Head Blight. Pages 4483 in: Fusarium Head Blight of Wheat and Barley, 512.

Johnson D. D., Flaskerud G. K., Taylor R. D., S aty anarayana V., 2003. Quantify ing Economic Impacts af Fusarium head blight in wheat. Pages 461483 in: Fusarium Head Blight of Wheat and Barley, 512.

Mauler Machnik A., Zahn K., 1994. Ear fusarioses in wheat new findings on their epide miology and control with Folicur (tebuconazole). Pflanzenschutz Nachrichten Bayer, 47 (2): 129155.

Mesterhazy A., B a r tok T., 2001. Control of Fusarium head blight with fungicides. Sustaina ble Systems of Cereal Crop Protection against Fungal Diseases as the Way of Reduction of Toxin Occurence in Food Webs. Book of Abstracts, 12.

Mielke H., Weinert J., 1996. Investigations on the effect of various fungicides on the patho gen of partial head blight (Fusarium culmorum/W.G.Sm./Sacc.). Nachrichtenblatt Dtsch. Pflanzenschutzdienstes, 48: 9395.

Parry D. W., Jenkins on P., McLeod L., 1995. Fusarium ear blight (scab) in small grains: A review. Plant Pathol. 44: 207238.

Treikale O., Guzeva L., 1996. Signification of Fusarium genus fungi for pathogenesis of root rot of cereals in Latvia. XIII Conf. on Fungi and Lichens in the Baltic Region. Riga, 6061.

Treikale O., Pug a cheva J., 2002. Causative agents of common root rot and bioefficiency of new fungicides for seed treatment of cereals. Proceeding of the scietifics international conference "Plant protection in the Baltic Region in the context of integration to EU", Kaunas, Akademija, 138140.

Tsumakov A. E., Zah a rova T. I., 1990. Vredonosnost boleznej selckohozjaistvennih kultur. Moskva, 127.

Tvaruzek L., 2001. New possibilities to control Fusarium head blight of wheat. Sustainable Systems of Cereal Crop Protection against Fungal Diseases as the Way of Reduction of Toxin Occurence in Food Webs. Book of Abstracts, 9.

\section{Zwalczanie fuzariozy kłosów pszenicy ozimej za pomocą sztucznego i naturalnego zakażenia przy zastosowaniu nowych fungicydów}

\section{Streszczenie}

Na Łotwie czynniki klimatyczne mają wpływ na szerzenie się fuzariozy zbóż wywołanej gatunkami Fusarium. Najważniejszym czynnikiem wpływającym na występowanie choroby w pszenicy ozimej jest podwyższona temperatura w czasie kwitnienia pszenicy. W latach 2003-2004 przeprowadzono badania polowe zwalczania choroby w pszenicy ozimej za pomocą nowych fungicydów stosowanych w różnej ilości poprzez naturalne zakażenie i sztuczną inokulację. Trzy gatunki czynników 
sprawczych: Fusarium avenaceum var. herbarum, F. gibbosum, F. culmorum, zebrano z zakażonych ziaren pszenicy i użyto do inokulacji poletek doświadczalnych przy stężeniu $10^{6}$ konidiów na $\mathrm{ml}^{-1}(1: 1: 1) \mathrm{w}$ fazie pełnego kwitnienia. Uzyskano skuteczne zwalczanie choroby poprzez zastosowanie nowych fungicydów z różnymi aktywnym składnikami: Prosaro 250 EC (tebukonazol $125 \mathrm{G}$, propikonazol $125 \mathrm{G} \mathrm{L}^{-1}$ ), Input $460 \mathrm{EC}$ (spiroksamina $300 \mathrm{G}$, propikonazol $160 \mathrm{G} \mathrm{L}^{-1}$ ). W warunkach sztucznego zakażenia poprzez ostry atak Fusarium spp., zastosowanie fungicydów zawierających tebukonazol w okresie czasu T3 dało znaczny wpływ na plon pszenicy ozimej poprzez zwiększenie pulchności ziaren. W badaniu uzyskano również wysoką skuteczność fungicydów w zwalczaniu zakażenia liści wywołanym przez Erysiphe graminis i Drechslera tritici-repentis.

Zastosowanie fungicydów zawierających cyprokronazol i trifloksystrobinę w okresie czasu T1 w badaniu w 2004 roku dało dobre zwalczanie Septoria tritici, E. graminis i D. tritici-repentis. 